\title{
Program Evaluation of Pekanbaru Health Training Center Based on Context Evaluation
}

\author{
Tin Gustina, Zulfiati Syahrial, Nurdin Ibrahim
}

\begin{abstract}
Objective of the study was generally to find out and describe the effectiveness of the implementation of health training at the Pekanbarau Health Training Center. This research is evaluation researchbased on the CIPP evaluation model (Context, Input, Process, Product) with the object of research is the BAPELKES program as a training center in Pekan Baru Riau, using a qualitative approach. This approach has a superiority that provides a comprehensive study of social phenomena carried out by researchers. The study used a mixed research approach (mixed methods), namely research that combines qualitative and quantitative approaches to answer research problems. Qualitative research is a process of scientific research to understand human problems in a social context by creating a comprehensive and complex picture presented, reporting detailed views of sources of information, and carried out in natural settings without any intervention from the researcher. The design of this study focused on four components of the CIPP evaluation model, namely context (Context), input (input), process (process), and results (product). The context component provides information for decision makers in planning a program that will continue, identifies the rational of a program, explains the relevant environmental conditions, describes the existing conditions, the foundation of program implementation, and identifies unmet needs and opportunities that have not been utilized. The results of the study show that the existence of BAPELKES as a training center is very much needed. Then it can be concluded that the context component of the evaluation program at the Pekan Baru Riau health education center has high / good actuality.
\end{abstract}

Keywords: Program Evaluation, Context Evaluation, CIPP.

\section{INTRODUCTION}

In the context of community development, various empowerment efforts have been carried out by the government and the private sector aimed at individuals, groups and communities. Empowerment efforts are in relation to the increasing demands on the world of work that requires the best quality of human or community resources. To answer the need for intelligent and quality human resources, education plays an important role. The 1945 Constitution states that one of the aims of the independence

Revised Manuscript Received on September 22, 2019

Tin Gustina, Post Graduated Departmen of Educational Technology Universitas Negeri Jakarta. Rawamangun muka street, Rawamangun Pulogadung, East Jakarta 13220, Indonesia. bunda.fitri@yahoo.co.id

Zulfiati Syahrial, Profesor at Universitas Negeri Jakarta. Rawamangun muka street, Rawamangun Pulogadung, East Jakarta 13220, Indonesia. zulfiati@unj.ac.id

Nurdin Ibrahim, Profesor at Universitas Negeri Jakarta. Rawamangun muka street, Rawamangun Pulogadung, East Jakarta 13220, Indonesia. nurdin@unj.ac.id of the Indonesian Nation is to educate the life of the nation. The range of the 1945 Constitution concerning education is stated in Law No. 20, 2003 article 3 states, "National education functions to develop capabilities and shape dignified character and national civilization in order to educate the nation's life, aiming at developing potential students to become human beings who believe and fear God Almighty, noble, healthy, knowledgeable, competent, creative, independent, and a democratic and responsible citizen.

National education functions to develop capabilities and form a dignified character and national civilization in order to educate the life of the nation, aiming to develop the potential of students to become dignified human beings in order to educate the nation's life, aiming at developing potential students to become faithful, pious human beings to God Almighty, noble, healthy, knowledgeable, capable, creative, independent, and a citizen of a democratic and responsible state. It can be concluded that the core of the purpose of education is the creation of quality Human Resources (HR).

To answer the need for intelligent and quality human resources, education plays an important role. The 1945 Constitution states that one of the aims of the independence of the Indonesian Nation is to educate the life of the nation. The range of the 1945 Constitution concerning education is stated in Law No. 20, 2003 article 3 states, "National education functions to develop capabilities and shape dignified character and national civilization in order to educate the nation's life, aiming at developing potential students to become human beings who believe and fear God Almighty, noble, healthy, knowledgeable, competent, creative, independent, and a democratic and responsible citizen.

The National Education System in Indonesia can be categorized in several ways, namely formal, non-formal and informal education, which can complement and enrich each other. It is said to be complementary because formal education also has limitations in preparing graduates to face the world of work.

The delivery of non-formal education emphasizes the process of democratization and flexibility that provides opportunities and freedom for the community to improve their knowledge and skills. Non-formal education is education carried out outside the path of formal education that can be carried out in a structured and tiered manner.

Talking about non-formal education does not mean only 
discussing non-formal education as an alternative education for the community but talking about non-formal education is talking about the concepts, theories and principles of education that are intact, which are in accordance with the conditions and needs of people's lives. Because non-formal education is an educational service that is not limited by time, age, sex, race (ethnicity, descent), socio-cultural conditions, economy, religion, and others. (Kamil, 2011). Non-formal education is recognized as having an important role in 'learning and training that takes place outside of educational institutions. This is said by Tight M. Key that:

suggests that while the latter concept of education and leaning throughout life, non-formal education is about acknowledging the importance of education, learning and training which takes place outside recognized education institution. ' (Tight, 1996)

Shows that on the contrary the concepts that are later related to the expansion of education and tend to be lifelong, can take place in non-formal education that recognizes the importance of education, learning and training that is recognized to take place outside of educational institutions.

Kamil also said that there are four basic characteristics related to non-formal education in the community: (1) relevant to the needs of disadvantaged groups of people (2), aimed at and having special attention to the categories of specific goals, (3) focused on programs that are in accordance with needs, (4) flexible in organizing and in learning methods. (Kamil, 2011)

Non-formal education, is expected to be the backbone of the development process through empowering the potential that exists in society by learning continuously or continuously, so as to foster a learning society. People who study continuously or throughout their lives want to describe unlimited learning, and that lasts for life, so that it improves life skills, both individually and society in all aspects of life. Thus, it is expected to increase independence, education and innovation in finding new information to improve their lives.

Since 2010, the existence of non-formal education has been recognized as an educational unit which includes course institutions, training institutions, study groups, taklim assemblies, and similar educational units.

One institution that functions in providing education services to citizens in relation to the learning community which has recently been promoted by the community and the government in collaboration with the community itself is the UPT for Health Crisis Management, Human Resource Development and Community Sports Health (PKKPSDMKOM). UPT from Riau Provincial Health Office. Geographically, the UPT. PKKPSDMKOM is in the area of Tobek Godang Sub-District, Tampan District, Pekanbaru City. Before the expansion of the location of the UPT.PKKPSDMKOM area was in the area of Delima Subdistrict Tampan. In 2016 after the expansion of the UPT.PKKPSDMKOM region which is currently in the Tobek Godang village. UPT.PKKPSDMKOM office space has an area of $\pm 2 \mathrm{Ha}$.

UPT. PKKPSDMKOM is located in the western region of
Simpang Baru Village, on the east bordering Maharatu Village. Whereas in the southern region bordering the West Sidomulyo Village. Then in the North it borders the Delima village.

UPT. PKKPSDMKOM has the task of carrying out work affairs and activities relating to handling crisis due to disasters, community sports health, training and health research. This task is stated in the Governor Regulation (PERGUB) No. 10 of 2014 concerning the Organization of Implementing Units at the Regional Technical Offices and Institutions within the Riau Provincial Government.

Profile of UPT Health Crisis Response, Human Resource Development and Community Sports Health Riau Provincial Health Office 2017 contains the results of achievement of activities that can be accounted for and problems encountered in the field and alternative solutions. In addition, this profile is useful to support the data and information needs needed to make decisions, plan, implement, monitor and evaluate activities.

Established in 1992 a health institution was established under the name KLKM (Community Health Training Course) which took place at Jl. Diponegoro No. 8 Pekanbaru. This institution is an institution formed by the Center for Education and Training (PUSDIKLAT) of the Ministry of Health of the Republic of Indonesia.

In 1993 it changed its name to Pekanbaru Health Training Center (BAPELKES) through the Decree of the Minister of Health No. 991 / Menkes / SK / X / 1993. Then in 1994, the Governor of Riau Soeripto was presented, and he donated 1.8 hectares, the land for the construction of the BAPELKES building on Jl. Pekanbaru - Bangkinang KM. 10 Panam. Building Physical Building is funded by the Asian Development Bank External Loan (ADB III).

With the enactment of Law Number 22 Year 1999, Regarding the Regional Government and Through the Decree of the Minister of Health dated August 23, 2001 Number 909 / Menkes / SK / III / 2001, regarding the transfer of several institutions / UPTs within the Ministry of Health to become Regional Apparatus Officially BAPELKES becomes UPT. Riau Provincial Health Office through Regional Regulation (PERDA) No. 18 of 2001.

In 2008, the Health Training Center (BAPELKES) changed its name to UPT. Health training and research (UPT. PELLITKES) in accordance with PERDA Riau No. 44 of 2008 and is a UPT. Riau Provincial Health Office

In 2009, UPT. Health Training and Research (UPT. PELLITKES), changed its name to the Health Research and Training Center (BAPELLITKES), the UPT of the Health Office. Riau Province.

In 2010, the Health Research and Training Center (BAPELLITKES) changed its name to, UPT. Health Training and Research (UPT. PELLITKES) Until 2014.

In early 2015, with the enactment of PERDA Riau No. 2 of 2014 concerning Regional Service Organizations, UPT. Health training and research (UPT. PELLITKES) changed its name to UPT. Health Crisis Response, Human Resource

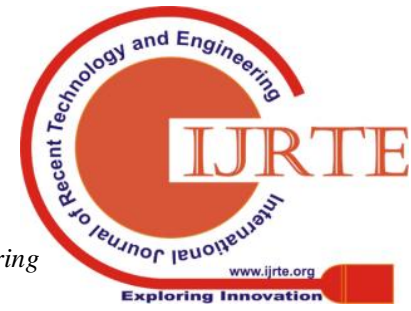


Development and Community Sports Health (UPT. PKKPSDM KOM)

In 2008, UPT. Health Training and Research (UPT. PELLITKES), has been accredited, based on the Decree of the Minister of Health of the Republic of Indonesia No. 725 / Menkes / SK / V / 2003, Regarding the Guidelines for Implementing Training in the Field of Health that every DIKLAT Organizing institution in the field of Health must be accredited by the Accreditation Team of the Health Education and Training Center. Then on April 1, 2008 Pekanbaru Bapelkes was accredited by obtaining a Certificate from the Health Education and Training Center (PUSDIKLAT) of the Indonesian Ministry of Health Number: HK.00.02.II.001839 / 2008. Then on July 1, 2016 UPTPKKPSDMKOM was re-accredited Based on the Decree of the Head of the Health Human Resources Development and Empowerment Agency No: HK. 01.07 / H.IV / 005804/2016. With full compliance Accredited.

Then at the beginning of 2018, the UPT.KKPSDMKOM office again changed its name from the UPT. PKKPSDMKOM becomes UPT. HEALTH TRAINING BALAI DEPARTMENT OF PROV. RIAU. Based on PERGUB Riau No. 64 of 2017. The name of the UPT. PKKPSDMKOM had disappeared from the recommendations of the Ministry of Home Affairs, and the discourse that emerged, the UPT. PKKPSDMKOM merges into UPT. Training under the Riau Province PPSDM Agency. But with all the struggles of stakeholders in Riau and also for the labors of the Health Office officials and UPT. PKKPSDMKOM, finally the UPT. PKKPSDMKOM is valid to be the UPT of the Riau Provincial Health Office, based on the PERGUB above. But the name changed to UPT. Health Office Training Center. Prov. Riau. And has the following organizational structure, Head of UPT, Head of Administration Subdivision, Head of Section of Training Organizers and Head of Quality Assessment, Development and Control Section (P3M)

\section{LITERATURE REVIEW}

Evaluation comes from the word evaluation (English) which means judgment. Evaluation experts formulate various definitions of evaluations with different formulations, but the core or contents are the same, namely giving consideration to achieving a goal and being used in decision making.

Daniel L. Stufflebeam (1986: 159) says that:"Evaluation is the process of delineation, obtaining, and providing descriptive and judgmental information about the worth and merit of an object's goals, design, implementation, and impact in order to guide decision making "

This definition describes a comprehensive evaluation starting from how the evaluation process is carried out, and what are the objectives to be achieved, and what are the benefits for the user / stakeholder. This evaluation focuses on the process, object, purpose and benefits of the evaluation results

Jean A. King, and Laurie Stevahn (2013: 13) said: Evaluation of information about characteristics, activities, and information about a valued purpose. Evaluation is a systematic inquiry process to provide good information about the characteristics, activities, or results of a program or policy for a valuable purpose.

This definition views evaluation as a systematic scientific process. The task of the evaluator in this definition is not only to seek information about the object being evaluated, moreover, the task of the evaluator's work evaluator is not to provide any information except information about the object being evaluated. So, it only focuses on the process and object of evaluation.

Louis Cohen, (et.all) (2010: 185) also says that, Evaluation is 'the provision of information about issues upon which decisions are taken'. Evaluation is' providing information about specific issues that underlie the assessment and from which decisions to an). This definition states that the benefits of evaluation to obtain accurate information whether policies in carrying out a program or policy have been taken with the right procedure and basis and focused on usability.

Mathison and Fournier (2010: 49) say that: Evaluation is applied inquiry process for collecting and synthesizing evidence that culminates in conclusions about the state of affairs, value, merit, worth, significance, or quality of a program, product, person, policy, proposal, or plan;

Evaluation is the process of applied investigations to collect and synthesize evidence culminating in conclusions about circumstances, values, propriety, appropriateness, significance, or quality of programs, products, people, policies, proposals, or plans. This definition describes the stages of the evaluation process, the objectives to be achieved and what objects can be evaluated. It focuses on the evaluation process and objectives.

Furthermore Donna M. Mertens (2009: 1) says that: Evaluation is defined as a systematic method of determining the merit, worth, or value of a program, policy, activity, technology, or similar entity to inform decision making about such entities ; Evaluation is defined as a systematic method for determining the appropriateness, appropriateness, or value of a policy program, activity, technology or similar entity to provide information in making decisions about the entity.

According to Arikunto et al (2006: 4) There are three important and important definitions in determining the program, namely: (1) realization or implementation of a policy, (2) occurring in a relatively long time - not a single activity but plural collaboration, and ( 3) occurs in organizations involving a group of people. Whereas The Join Conference is Standards for Educational Evaluation (1997: 7-8), defines a program as: "activities that are provided on a continuing basis." But in full, the program is not only interpreted as a set of activities, but more than that, the program is; a set of activity plans arranged systematically; use resources; achieve a final(goalgoal); based on need; having specificity, being identified, interested in a group or individual; in a special context; have 
documented results as outputs, outcomes, and impacts; and have a reliable follow-up system.

Programs according to Trias Teknodik Managers in Sukardi (2014: 4) are "educational activities that are provided on continuing based" (programs are educational activities that are routinely provided).

Non-formal education in the implementation of its programs has a variable management unit model. The unit models that are built are very dependent on program needs, student goals and program development interests. The size of the institutional management unit model and the extent of the targets developed are largely determined by the ability of the developer (provider) to understand the types of programs to be built.

According to Maimun (2016: 62) The program evaluation model chosen in relation to this research is the evaluation of the CIPP program (Content, Input, Process, Product). CIPP evaluation includes four types of decisions, namely: (1) planning decisions, namely decisions that influence the choice of program goals and objectives (maintaining existing, modifying, and developing); (2) Structuring decisions, namely decisions that ensure the strategy and design of procedures to achieve the objectives previously set; (3) Implementing decisions, namely decisions that provide procedures for implementing programs and improving the design, methods and strategies chosen; (4) Recycling decisions, namely decisions that determine whether the activity or program itself needs to be continued, revised, and terminated.

According to Farnas Dan Ali (2016: 571-579) The selection of the CIPP evaluation model is based on the consideration that the CIPP evaluation model is one of the most effective systematic models based on management that focuses on the effectiveness and quality of the education system. In addition According to Asfaroh et al (2017: 1999-2010) the CIPP model is also effective for formative and summative evaluations and for obtaining decisions and problem solving where this evaluation model considers a program as a system, so program evaluation as a system must be implemented in detail based on components - components included in the model.

Specifically, the context evaluation component of the Context, Input, Process, and Product evaluation can identify service providers' learning needs and the community's needs. The component can then help prescribe a responsive project that can best address the identified needs. Next, the process evaluation component monitors the project process and potential procedural barriers and identifies needs for project adjustments. Finally, the product evaluation components are measures, interprets, and project judges' outcomes and interprets their merit, worth, significance, and probity.

Zhang, et.al (2011: 57) in more detail suggests that the evaluation model can help identify the needs of students, service providers and the community. The input evaluation component can help explain that needs are well identified, process evaluation components monitor processes and possible procedural barriers, while product components measure, interpret, and assess results, feasibility, values, significance, programs.

\section{Methodology/Materials}

The general purpose of the study was to find out and describe the effectiveness of the implementation of PKBM as a learning resource in the Municipality of Ambon. This research isevaluation researchbased on the CIPP evaluation model (Context, Input, Process, Product) with the object of research is the PKBM program as a source of community learning resources in Ambon city, using a qualitative approach. This approach has a superiority that provides a comprehensive study of social phenomena carried out by researchers.

According to Sugiono (2008: iii) In general, research methods can be classified into three, namely qualitative quantitative methods, and methods research and development. Creswell states that, qualitative research is a process of scientific research to understand human problems in a social context by creating a comprehensive and complex picture presented, reporting detailed views of sources of information, and carried out in natural settings without any intervention from the researcher.

\section{RESULTS AND FINDINGS}

The existence of BALPEKES as a training center is very much needed so that the active participation of health office staff is needed to rebuild educational activities through empowering existing potentials.

The formulation involves all the elements involved in the training center. This shows that BALPEKES has an interest in making its vision and mission a shared vision that encourages and motivates all interested parties to participate as much as possible and has a commitment to achieve the goal of establishing BALPEKES.

Component context(context)CLC program as a health training in Pekan Baru Riau, include the environmental conditions underlying the program implementation training program, c) the vision, mission, and objectives, and d) the target BALPEKES.

\section{A. Background of the Establishment}

UPT. PKKPSDMKOM has the task of carrying out work affairs and activities relating to handling crisis due to disasters, community sports health, training and health research. This task is stated in the Governor Regulation (PERGUB) No. 10 of 2014 concerning the Organization of Implementing Units at the Regional Technical Offices and Institutions within the Riau Provincial Government. Some of the factors behind the establishment of BALPEKES based on the findings of the findings in the field include the following:

\section{B. Fulfilling educational needs}

One of the main tasks of the UPT Health Crisis Management, Human Resource Development and Community Sports Health Riau Provincial Health Office is to carry out administrative management administration, financial,

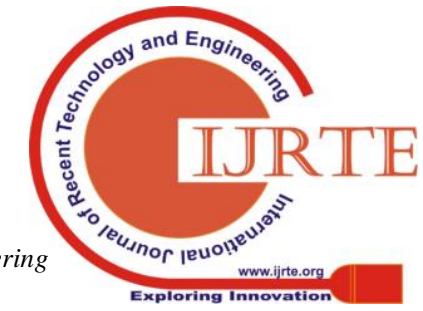


equipment, personnel, organization, management, public relations, law and other tasks within the UPT. PKKPSDMKOM .

Profile of UPT Health Crisis Response, Human Resource Development and Community Sports Health Riau Provincial Health Office 2017 contains the results of achievement of activities that can be accounted for and problems encountered in the field and alternative solutions. In addition, this profile is useful to support the data and information needs needed to make decisions, plan, implement, monitor and evaluate activities.

Established in 1992 a health institution was established under the name KLKM (Community Health Training Course) which took place at Jl. Diponegoro No. 8 Pekanbaru. This institution is an institution formed by the Center for Education and Training (PUSDIKLAT) of the Ministry of Health of the Republic of Indonesia.

In 1993 it changed its name to Pekanbaru Health Training Center (BAPELKES) through the Decree of the Minister of Health No. 991 / Menkes / SK / X / 1993. Then in 1994, the Governor of Riau Soeripto was presented and he donated 1.8 hectares, the land for the construction of the BAPELKES building on Jl. Pekanbaru - Bangkinang KM. 10 Panam. Building Physical Building is funded by the Asian Development Bank External Loan (ADB III).

In 2008, the Health Training Center (BAPELKES) changed its name to UPT. Health training and research (UPT. PELLITKES) in accordance with PERDA Riau No. 44 of 2008 and is a UPT. Riau Provincial Health Office

In 2009, UPT. Health Training and Research (UPT. PELLITKES), changed its name to the Health Research and Training Center (BAPELLITKES), the UPT of the Health Office. Prov ,. Riau.

In 2010, the Health Research and Training Center (BAPELLITKES) changed its name to, UPT. Health Training and Research (UPT. PELLITKES) Until 2014.

In early 2015, with the enactment of PERDA Riau No. 2 of 2014 concerning Regional Service Organizations, UPT. Health training and research (UPT. PELLITKES) changed its name to UPT. Health Crisis Response, Human Resource Development and Community Sports Health (UPT. PKKPSDM KOM)

In 2008, UPT. Health Training and Research (UPT. PELLITKES), has been accredited, based on the Decree of the Minister of Health of the Republic of Indonesia No. 725 / Menkes / SK / V / 2003, Regarding the Guidelines for Implementing Training in the Field of Health that every DIKLAT Organizing institution in the field of Health must be accredited by the Accreditation Team of the Health Education and Training Center. Then on April 1, 2008 Pekanbaru Bapelkes was accredited by obtaining a Certificate from the Health Education and Training Center (PUSDIKLAT) of the Indonesian Ministry of Health Number: HK.00.02.II.001839 / 2008. Then on July 1, 2016 UPTPKKPSDMKOM was re-accredited Based on the Decree of the Head of the Health Human Resources Development and Empowerment Agency No: HK. 01.07 / H.IV / 005804/2016. With full compliance Accredited.
Then at the beginning of 2018, the UPT.KKPSDMKOM office again changed its name from the UPT. PKKPSDMKOM becomes UPT. HEALTH TRAINING BALAI DEPARTMENT OF PROV. RIAU. Based on PERGUB Riau No. 64 of 2017. The name of the UPT. PKKPSDMKOM had disappeared from the recommendations of the Ministry of Home Affairs, and the discourse that emerged, the UPT. PKKPSDMKOM merges into UPT. Training under the Riau Province PPSDM Agency. But with all the struggles of stakeholders in Riau and also for the labors of the Health Office officials and UPT. PKKPSDMKOM, finally the UPT. PKKPSDMKOM is valid to be the UPT of the Riau Provincial Health Office, based on the PERGUB above. But the name changed to UPT. Health Office Training Center. Prov. Riau. And has the following organizational structure, Head of UPT, Head of Administration Subdivision, Head of Section of Training Organizers and Head of Quality Assessment, Development and Control Section (P3M)

\section{Legal Basis for Implementing PKBM}

Article 28 paragraph 1 of the Constitution of the Republic of Indonesia mandates that "Everyone has the right to develop themselves through fulfilling their basic needs, having the right to education and obtaining benefits from science and technology, art and culture in order to improve their quality of life for the welfare of the people human".

The mandate of the 1945 Constitution above was implemented by the government by stipulating Law Number 20 of 2003 concerning the National Education System which in Article 13 paragraph 1 of this Law classifies education channels for formal education, non-formal education, and informal education that can complement each other and enrich. Thus it can be understood that PKBM as a Nonformal Education unit whose establishment is a learning initiative from, by, and for the community, is an integral part of the national education system whose purpose is to educate the nation's life and develop Indonesian people as a whole, namely believers and devotees to God The One and noble character, have knowledge and skills, physical and spiritual health, a solid and independent personality and a sense of social and national responsibility.

Article 26 paragraph 1 of Law No.20 of 2003 concerning National Education System states that "non-formal education is held for citizens who need educational services that function as substitutes, enhancers, and / or complementary formal education in order to support lifelong education". The establishment of non-formal education institutions is regulated in the regulation of the minister of education and culture of the Republic of Indonesia number 81 of 2013 concerning the establishment of non-formal education units which in article 2 states that PNF Units can be established by: a) individuals; b) groups of people; and / or; c) legal entity fulfilling the requirements stipulated in article 5 of this rule which consists of administrative requirements and technical requirements. The

description and information

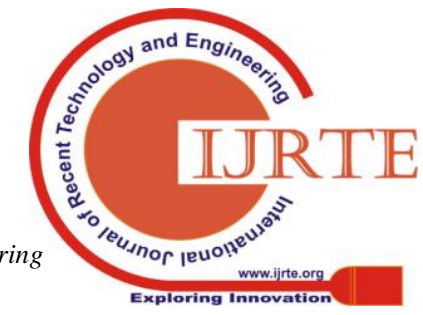


above illustrate that the implementation of BALPEKES has a solid legal basis to be able to organize training programs.

\section{Vision, Mission, and Objectives of PKBM}

Implementation of Health Service Training. Prov. Riau is intended to provide training services for health workers in Riau Province.

The objectives mentioned above are reflected in the vision and mission specified, namely: "fast, smart, ready to work, capable of independent business. Specifically an explanation of BALPEKES's vision, namely: 1) increasing the intelligence of training participants who are innovative, creative, and independent, 2) developing the training participants' creativity according to their talents to be ready for work, and 3) creating training participants who have the potential, talents, and morals the good one.

To realize the vision above, BALPEKES establishes the mission as follows: 1) realizing personal training participants who are smart, ready to work, capable of independent business, and 2) create a learning environment that is friendly to training participants.

\section{E. Program Objectives}

In accordance with its function and role as a training center has an important role in developing training programs for employees in Riau Province by organizing continuous training programs. The target of the education and training program is all health employees in Riau Province.

Based on the results of the components of the context as outlined above, the results of the evaluation of this component are summarized in the matrix as follows:

Table 4.1: Results of evaluation of context components based on objective standards BALPEKES Riau

\begin{tabular}{|c|c|c|c|}
\hline $\begin{array}{l}\text { Standard } \\
\text { Objective }\end{array}$ & $\begin{array}{l}\text { The intensity of } \\
\text { theObjective }\end{array}$ & $\begin{array}{c}\text { Crite } \\
\text { ria }\end{array}$ & Decision \\
\hline $\begin{array}{l}\text { legal basis for the } \\
\text { establishment of } \\
\text { BALPEKES }\end{array}$ & $\begin{array}{l}\text { EstablishmentBALP } \\
\text { EKES have a strong } \\
\text { foundation of the } \\
\text { necessary provision } \\
\text { of alternative } \\
\text { education access } \\
\text { The legal basis for } \\
\text { implementing } \\
\text { BALPEKES is } \\
\text { clear } \\
\text { BALPEKES fulfills } \\
\text { the } \\
\text { administrative } \\
\text { requirements for } \\
\text { establishment } \\
\text { and operational } \\
\text { permits for the } \\
\text { implementation } \\
\text { of }\end{array}$ & $\begin{array}{l}\text { High } \\
/ \\
\text { Good }\end{array}$ & $\begin{array}{l}\text { Based on } \\
\text { the } \\
\text { evaluation } \\
\text { component } \\
\text { of the } \\
\text { program } \\
\text { context } \\
\text { BALPEKE } \\
\text { S have high } \\
\text { topicality / } \\
\text { good }\end{array}$ \\
\hline
\end{tabular}

Vision, mission, and objectives BALPEKES

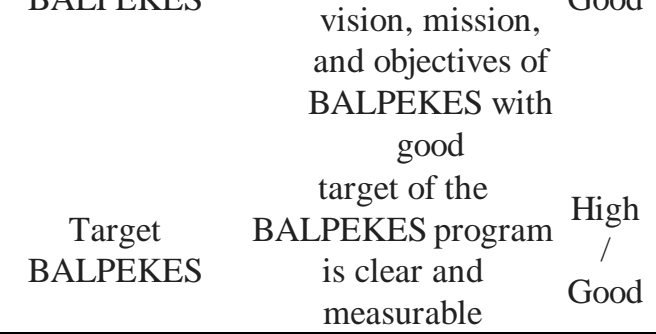

\section{CONCLuSION}

The existence of BALPEKES as a training center is indeed very much needed by the people of Pekanbaru Riau so that active participation of health staff is needed to rebuild educational activities through empowering the potentials available through BALPEKES.

The health training program in Pekanbaru Riau has a very strong legal basis, because the law is guaranteed. In addition, BALPEKES has the minimum administrative requirements needed to establish BALPEKES and obtain an operational permit from the Ministry of Internal Affairs. so, training participants who take part in the training program can take part in the training well.

The formulation involves all elements involved in the health office and socialized to all employees through various techniques. This shows that BALPEKES has an interest in making its vision and mission a shared vision that encourages and motivates all interested parties to participate as much as possible and has a commitment to achieve the goal of establishing BALPEKES.

\section{ACKNOWLEDGEMENTS:}

This research work is supported by Health Training Center (BAPELKES) Riau.

\section{REFERENCES}

[1] Arikunto, Suharsini dan Cepi Saffrudin Abdul Jabar. Evaluasi Program Pendidikan Pedoman Teoretis Praktis Bagi Mahasiswa dan Praktisi Pendidikan. Jakarta: Bumi Aksara Cet. ketiga 2009,

[2] Andrea Honigsfeld and Audrey Cohan, Breaking the Mold of School Instruction and Organization : Innovative and Successful Practices for the Twenty-first Century, (Maryland: The Rowman \& Littlefield . Inc., 2010

[3] Creswell W. Jhon. Research Design: Pendekatan Kualitatif, Kuantitatif, dan Mixed. Cetakan III. Yogyakarta: Pustaka Belajar, 2013.

[4] Charles M. Reigeluth, Instructional Design Theories and Models: An Overview of Their Current Status (New Jersey: Lawrence Erlbaum, 1983

[5] Data Pendidikan Kesetaraan, Dinas Pendidikan Kota Ambon, 2018.

[6] Donna M. Mertens, Research and evaluation in education and psychology : integrating diversity with quantitative,qualitative, and mixed methods, California: Sage Publication, 2010

[7] Transformative research and evaluation, New York: Guilford Press, 2009. 
[8] Farnaz Limouei and Omid Ali Hoseinzadeh, An Internal Evaluation of Educational Groups in Dentistry Faculty of Tabriz Medical University Using CIPP model in 2015, International Journal of Medical Research \& Health Sciences, (2016), Vol. 5 (11)

[9] Guili Zhang, et.al., Using the Context, Input, Process, and Product Evaluation Model (CIPP) as a Comprehensive Framework to Guide the Planning, Implementation, and Assessment of Service-learning Programs, Journal of Higher Education Outreach and Engagement, Vol 15, (4), (2011)

[10] Jean A. King, and Laurie Stevahn, Interactive Evaluation Practice: Mastering the Interpersonal Dynamics of Program Evaluation,.California: Sage Publication,2013.

[11] Jodi L. Fitzpatrick et.al., Program Evaluation: Alternative Approaches Practical Guidelines. New York: Longman, 1997

[12] Kementerian Pendidikan dan Kebudayaan, Ikhtisar Data Pendidikan Tahun 2016/2017, (Jakarta: Pusat Data dan Statistik Pendidikan dan Kebudayaan, 2017), h. 26

[13] Louis Cohen, (et. all), A guide to teaching practice: revised edition, New York: Routledge, 2010

[14] Mustofa, Kamil. Pendidikan Nonformal. Pengembangan Melalui Pusat Kegiatan Belajar (PKBM) di Indonesia. Bandung: Alfabeta, 2011.

[15] Maimun. Evaluasi Program Parenting Pada Program Pendidiksan Anak Usia Dini (PAUD) di Kota Mataram. Disertasi PPS-TP UNJ, 2016.

[16] Philip G. Kapfer, Miriam B. Kapfer, Learning Packages in American Education, (New Jersey: Educational Technology Publication, 1972

[17] Ronald R. Sims nd Serbrenia J. Sims. The Importance of Learning Styles : Understanding the Implications for Learning, Course Design, And Education

[18] Standard dan Prosedur Penyelenggaraan Pusat Kegiatan Belajar Masyarakat (PKBM) Jakarta: Kementerian Pendidikan dan Kebudayaan, 2012

[19] Stufflebeam Daniel L, and Anthony J. Shinkfield. Systematic Evaluation: A Self-Instructional Guide to Theory and Practice. Dordrecht: Kluwer-Nijhoff Publising, 1986

[20] Sukardi. Evaluasi Program Pendidikan dan Kepelatihan. Jakarta: Bumi Aksara, 2014.

[21] Sitepu, B.P, Pengembangan Sumber Belajar, Jakarta: PT RajaGrafindo Persada, 2014

[22] Sugiyono, Metode Penelitian Pendidikan: Pendekatan Kuantitatif, Kualitatif dan R\&D (Bandung: Alfabeta, 2008

[23] Tanka Nath Sharma, Education for Rural Transformation: The Role of Community Learning Centers in Nepal. Journal of Education and Research, Vol. 4, No. 2, 2014

[24] Tight M.(1996). Key Concepts in Adult Education and Training. London: Routledge.

[25] Wirawan, Evaluasi Teori Model, Standard, Aplikasi dan Prosesi (Contoh Aplikasi Evaluasi Program: Pengembangan Sumber Daya Manusia, Program Nasional Pemberdayaan Masyarakat (PNPM), Mandiri Pedesaan, Kurikulum, Perpustakaan, dan Buku Teks (Jakarta: RadjaGrafindo Persada, 2012),

[26] Worthen, B.R. and J.R. Sanders. Educational Evaluation: Theory and practice. 1975.

[27] Yahui Su and Liyia Feng, Community Service as a Lifelong Learning Practice: Themes and Hypotheses, International Journal of Humanities and Social Science, Vol. 4 No. 4. 2014

\section{AUTHORS PROFILE}

I am Tin Gustina, I am associated Post Graduated Departmen of Educational Technology Universitas Negeri Jakarta. Rawamangun muka street, Rawamangun Pulogadung, East Jakarta 13220, Indonesia. My area of interest is education.

My name is Zulfiati Syahrial, Profesor at Universitas Negeri Jakarta. Rawamangun muka street, Rawamangun Pulogadung, East Jakarta 13220, Indonesia. My area of interest is education.

My name is Nurdin Ibrahim, Profesor at Universitas Negeri Jakarta. Rawamangun muka street, Rawamangun Pulogadung, East Jakarta 13220, Indonesia. My area of interest of education. 